\title{
Fast growth associated with aberrant vasculature and hypoxia in fibroblast growth factor 8b (FGF8b) over-expressing PC-3 prostate tumour xenografts
}

\author{
Johanna Tuomela ${ }^{1,2^{*}}$, Tove J Grönroos ${ }^{3}$, Maija P Valta ${ }^{1}$, Jouko Sandholm ${ }^{4}$, Aleksi Schrey ${ }^{5}$, Jani Seppänen ${ }^{1,2}$, \\ Päivi Marjamäki ${ }^{3}$, Sarita Forsback ${ }^{6}, \|$ po Kinnunen ${ }^{5}$, Olof Solin ${ }^{7}$, Heikki Minn ${ }^{8}$, Pirkko L Härkönen ${ }^{1,9}$
}

\begin{abstract}
Background: Prostate tumours are commonly poorly oxygenated which is associated with tumour progression and development of resistance to chemotherapeutic drugs and radiotherapy. Fibroblast growth factor 8b (FGF8b) is a mitogenic and angiogenic factor, which is expressed at an increased level in human prostate tumours and is associated with a poor prognosis. We studied the effect of FGF8b on tumour oxygenation and growth parameters in xenografts in comparison with vascular endothelial growth factor (VEGF)-expressing xenografts, representing another fast growing and angiogenic tumour model.
\end{abstract}

Methods: Subcutaneous tumours of PC-3 cells transfected with FGF8b, VEGF or empty (mock) vectors were produced and studied for vascularity, cell proliferation, glucose metabolism and oxygenation. Tumours were evaluated by immunohistochemistry $(\mathrm{IHC})$, flow cytometry, use of radiolabelled markers of energy metabolism $\left({ }^{18} \mathrm{~F}\right]$ $\mathrm{FDG}$ ) and hypoxia $\left(\left[{ }^{18} \mathrm{~F}\right] \mathrm{EF} 5\right)$, and intratumoral polarographic measurements of $\mathrm{pO}_{2}$.

Results: Both FGF8b and VEGF tumours grew rapidly in nude mice and showed highly vascularised morphology. Perfusion studies, $\mathrm{pO}_{2}$ measurements, $\left[{ }^{18} \mathrm{~F}\right] \mathrm{EF} 5$ and $\left[{ }^{18} \mathrm{~F}\right] \mathrm{FDG}$ uptake as well as $\mathrm{IHC}$ staining for glucose transport protein (GLUT1) and hypoxia inducible factor (HIF) 1 showed that VEGF xenografts were well-perfused and oxygenised, as expected, whereas FGF8b tumours were as hypoxic as mock tumours. These results suggest that FGF8b-induced tumour capillaries are defective. Nevertheless, the growth rate of hypoxic FGF8b tumours was highly increased, as that of well-oxygenised VEGF tumours, when compared with hypoxic mock tumour controls.

Conclusion: FGF8b is able to induce fast growth in strongly hypoxic tumour microenvironment whereas VEGFstimulated growth advantage is associated with improved perfusion and oxygenation of prostate tumour xenografts.

\section{Background}

Hypoxia is a common feature of prostate tumours [1]. A low oxygen concentration is known to make tumour cells resistant to radiation therapy and chemotherapy [2]. Furthermore, there is evidence that hypoxia may lead to increasingly malignant behaviour of tumour cells $[3,4]$. Hypoxia leads to disruption of microenvironmental homeostasis in tumours, where metabolic changes, involving diffusion gradients of oxygen and glucose, develop at microregional level [5]. A common

\footnotetext{
* Correspondence: jomitu@utu.fi

'Institute of Biomedicine, Department of Cell Biology and Anatomy,

University of Turku, Turku, Finland

Full list of author information is available at the end of the article
}

feature of invasive cancers is altered glucose metabolism, including both aerobic and anaerobic glycolysis [6]. Conversion of glucose to lactic acid in the presence of oxygen is known as aerobic glycolysis or the "Warburg effect". The molecular mechanisms leading to upregulated glycolysis in tumours are not well known, but increased glucose uptake and elevated expression of glucose transporters (GLUTs), such as GLUT1, are commonly seen in tumour cells [7]. In prostate cancer, the expression of GLUT1 is also correlated with Gleason score [8]. Members of the GLUT gene family are known to be regulated by hypoxiainducible transcription factor 1 (HIF1), which is strongly upregulated under hypoxic conditions [9].

\section{Ciomed Central}


Tumour hypoxia is also related with increased angiogenesis which is primarily stimulated by HIF1-induced vascular endothelial growth factor (VEGF) but also by other tumour cell produced cytokines and growth factors including fibroblast growth factors (FGFs) [10,11]. Regardless of neovascularisation, tumours are often poorly oxygenated due to disorganised and leaky vessels [2]. VEGF is a mitogen for vascular endothelial cells but not for other cell types $[12,13]$. It induces a strong angiogenic response in different in vivo models and increases vascular permeability, which is essential to angiogenesis associated with tumour growth and wound healing [14]. In human prostate cancer patients, the expression of VEGF correlates with Gleason score and occurrence of lymph node metastasis $[15,16]$ as well as the poor outcome of radical treatment of localised prostate cancer [17].

The family of FGFs plays an important role in many physiological processes including development [18], wound healing [19], angiogenesis [20], bone formation and osteoblast differentiation [21]. Studies of our own and others on FGF8 have shown that reciprocal FGF/ FGF receptor mediated interactions between tumour cells and stromal cells play important roles in prostate cancer progression and angiogenesis [20,22-26]. Fibroblast growth factors 1, 2, 6, 9 and 17 are also expressed at high levels in prostate cancer, where they may function as paracrine and/or autocrine mediators [22,27].

Fibroblast growth factor 8 was originally cloned from conditioned medium of mouse mammary tumour-derived SC-3 cells and was identified as androgen-induced growth factor (AIGF) [28]. Four human FGF8 isoforms, named FGF8a, FGF8b, FGF8e and FGF8f, are formed by alternative splicing [29]. FGF8b has been found to be the most transforming of these isoforms and FGF8b targeted to prostate epithelium causes prostatic intraepithelial neoplasia (PIN) lesions in transgenic mice [30]. FGF8b is also the major isoform expressed in prostate cancer $[17,26,31,32]$. FGFs mediate their effects by binding to specific tyrosine kinase receptors (FGFR1-4), which all are expressed in prostate cancer $[18,33]$. The in vitro and in vivo studies have shown that FGF8b increases growth, invasion, tumorigenesis, angiogenesis and bone metastasis in experimental breast $[23,34,35]$ and prostate cell lines and tumours [20,36-38]. FGF8b is a strongly angiogenic factor, which property has been considered to contribute to increased tumour growth $[20,23]$. In human prostate cancer, the expression of FGF8b has been shown to predict a poor prognosis [17,32].

We aimed to study whether FGF8b-induced rich neovascularisation is able to influence oxygenation of prostate tumour microenvironment and influence tumour growth by these mechanisms. PC-3 cells were used to create models for prostate cancer expressing VEGF or FGF8b, which both are known to be angiogenic and to be increased in prostate cancer. Nude mice were subcutaneously inoculated with $\mathrm{PC}-3$ cells transfected with FGF8b, VEGF or empty vectors. PC-3/VEGF cells were used as "positive" controls because they were expected to produce well-vascularised and oxygenised tumours. The FGF8b tumours were studied for growth rate, vascularisation, energy metabolism as well as tumour hypoxia and oxygenation, and the findings were compared with those from VEGF and mock tumours, which served as positive and negative controls, respectively.

\section{Methods}

\section{Cell culture and transfection}

The human hormone-resistant prostate cancer cell line PC-3 was obtained from the American Tissue-Type Culture Collection (Rockville, MD, USA). PC-3 cells, which were stably transfected with FGF8b (PC-3/FGF8b) were used as previously described [38]. Stable VEGF transfection was carried out by using the expression vector pcDNA3.1(+) (Invitrogen, CA, USA) containing human VEGF cDNA in an ECORI site (kindly provided by Prof. Kari Alitalo, University of Helsinki, Finland, [39]) and empty pcDNA3.1(+) vector-transfected cells (mock) were used as controls. Neomycin $(\mathrm{G} 418,500 \mu \mathrm{g} / \mathrm{mL})$ was added to culture media of transfected PC-3 cells for the selection of clones. At near confluence, the cells were harvested in trypsin/EDTA (Biochrom AG, Germany), washed with culture medium and finally suspended at a concentration of $1 \times 10^{6} / 100 \mu \mathrm{L}$ in sterile phosphate-buffered saline solution (PBS, Biochrom AG, Germany). The cells were kept on ice until inoculation.

\section{Northern and Western blot analysis}

Total RNA was extracted from PC-3 cells using the guanidinium isothiocyanate method [40]. Northern blotting was performed as previously described [41]. Serum-free DMEM conditioned by FGF8b, VEGF and mock cells was harvested from the cultures as previously described [42]. Heparin-sepharose-bound proteins were extracted by 5 -min incubation in Laemmli sample buffer at $95^{\circ} \mathrm{C}$ and separated by sodium dodecyl sulphate-polyacrylamide gel electrophoresis. After transfer to nitrocellulose membranes (Bio-Rad), proteins were detected by using goat polyclonal anti-FGF8b neutralising antibodies [20] and anti-human VEGF antibodies (both from R\&D systems, Minneapolis, MN, USA). Horseradish peroxidaselabelled anti-goat IgG (DAKO, Denmark) was used as a secondary antibody. Protein bands were visualised by using an ECL chemiluminescence detection system (GE, Healthcare Biosciences, Uppsala, Sweden).

\section{Animals and tumour models}

Eight-week-old male athymic nu/nu mice (Harlan, the Netherlands) were maintained under controlled 
pathogen-free environmental conditions $\left(20-21^{\circ} \mathrm{C}\right.$, $30-60 \%$ relative humidity and a 12 -hour lighting cycle). FGF8b, VEGF and mock cells were inoculated subcutaneously $\left(1 \times 10^{6}\right.$ cells in $100 \mu \mathrm{L}$ PBS $)$ into the back of the neck. The animals were monitored daily for clinical signs. Tumour measurements were performed once a week and tumour volume was calculated according to the formula $\mathrm{V}=(\pi / 6)\left(\mathrm{d}_{1} \times \mathrm{d}_{2}\right)^{3 / 2}$ [43], where $\mathrm{d}_{1}$ and $\mathrm{d}_{2}$ are perpendicular tumour diameters. The tumour volume was expressed as mean \pm SEM. The animal experiments were carried out according to the European Convention for the Protection of Vertebrate Animals used for Experimental and other Scientific Purposes, plus Statutes 1076/85 $\mathbb{S}$ and $1360 / 90$ of The Animal Protection Law in Finland, and EU Directive $86 / 609$. The experiment procedures were reviewed by the local Ethics Committee on Animal Experimentation at the University of Turku and approved by the local Provincial State Office of Western Finland.

\section{Tumour morphology and immunohistochemical analyses}

Morphological evaluation of tumours was determined from frozen sections stained with haematoxylin and eosin (H\&E) using standard techniques. Frozen sections $(10 \mu \mathrm{M})$ were cut, and fixed with ice-cold acetone for 10 minutes at $4{ }^{\circ} \mathrm{C}$. Sequential frozen sections were incubated with antibodies against CD31 (BD Biosciences, Pharmingen, CA, USA), Ki67 (Novocastra Laboratories Ltd., Newcastle upon Tyne, UK) and GLUT1 (Alphadiagnostics, TX, USA) o/n at $4^{\circ} \mathrm{C}$. HIF1 (BD Biosciences, Pharmingen, CA, USA) antibody was used on formalinfixed, paraffin-embedded tumour slides $\mathrm{o} / \mathrm{n}$ at $4{ }^{\circ} \mathrm{C}$. The samples were then treated with biotin-labelled rabbit anti-mouse (DAKO Denmark A/S, Glostrup, Denmark or Vectastain CA, USA) secondary antibodies. A mouse-onmouse kit (Vector Laboratories, Burlingame, CA, USA) was used in the Ki67 antibody staining procedure in order to inhibit non-specific staining of anti-mouse secondary antibodies. Visualisation of the primary antibodies was carried out by using Vectastain ABC reagent and a diaminobenzidine substrate kit (Vector Laboratories, Burlingame, CA, USA), the methodology which is based on the indirect streptavidin-biotin method. The slides were later counterstained with Meyer's haematoxylin. Negative controls (sections of every sample stained without the primary antibody) were used to verify the specificity of staining. Three representative non-overlapping fields inside each tumour were analysed microscopically (Leica, DMRB, Leica Microsystems, Heerburg, Germany) and images were taken with a digital camera (Leica DC 300F, Leica Microsystems, Heerburg, Germany). The lengths of CD31-positive vessels were counted in each tumour by drawing lines following stained vessels and measuring the length of the lines using ImageJ software
(ImageJ, 1.37v, Wayne Rasband, National Institutes of Health, USA) [44]. The relative numbers of Ki67and GLUT1-positive cells were counted in three nonoverlapping sections at $500-\mu \mathrm{m}$ intervals. Altogether, 1.000-3.000 cells/tumour were counted [44]. The results were blind-tested by two independent analysers comparing study versus control samples.

The relative proportion of necrotic tissue was determined in representative H\&E-stained tumour slides using the ImageJ software. The evaluation was based on morphological features of the tissue.

The perfusion marker Hoechst 33342 was intravenously injected into tumour-bearing nude mice two minutes before sacrifice in order to study the intratumoral perfusion pattern. Images were acquired from frozen sections $(10 \mu \mathrm{m})$ using a Zeiss AxioVert $200 \mathrm{M}$ fluorescence microscope (Zeiss $\mathrm{GmbH}$, Jena, Germany).

\section{Flow cytometry}

Three tumours from each group were collected in icecold PBS supplemented with pepsin (0.5\%, pH 1.4, Merck, Darmstadt, Germany) immediately after sacrifice of the mice. Tumour tissue was homogenised with Ultra-Turrax equipment (Rose Scientific Ltd., Canada) and incubated at $37^{\circ} \mathrm{C}$ for $1 \mathrm{~h}$. The suspension was collected and filtered prior to analysis. For cell cycle analysis, tumour homogenate was incubated in hypotonic buffer (PBS with $1 \%$ Triton X-100 and propidium iodide at $0.05 \mathrm{mg} / \mathrm{mL}$ ) for $20 \mathrm{~min}$ at $4^{\circ} \mathrm{C}$. The fractions of cell cycle phases (G0/G1, S and G2/M) were calculated with ModFit cell cycle modelling software (Verity Software House, Inc., Topsham, ME, USA). For cell enumeration, cells were analysed using TrueCount tubes (Becton Dickinson, CA, USA). Briefly, the number of cells in the tube was calculated by comparing a known number of beads in the tube with cell number in a known volume. All flow cytometry was performed using a FACSCalibur (Becton Dickinson, CA, USA) flow cytometer and CellQuestPro software (Becton Dickinson, CA, USA).

\section{$\left[{ }^{18} \mathrm{~F}\right] \mathrm{EF} 5$ and $\left[{ }^{18} \mathrm{~F}\right] \mathrm{FDG}$ uptake in tumours}

${ }^{18}$ F-labelled EF5 (2-(2-nitro-1H-imidazol-1-yl)- $N$ (2,2,3,3,3-pentafluoropropyl)-acetamide) was synthesised from 2-(2-nitro-1H-imidazol-1-yl)- $N$-(2,3,3-trifluoroallyl)-acetamide using high specific radioactivity ${ }^{18} \mathrm{~F}-\mathrm{F}_{2}$ as the labelling reagent [45]. The specific radioactivity of $\left[{ }^{18} \mathrm{~F}\right] \mathrm{EF} 5$, decay corrected to the end of synthesis, exceeded $3.7 \mathrm{GBq} / \mu \mathrm{mol}$. Radiochemical purity was higher than $98.5 \%$ in every production batch. ${ }^{18} \mathrm{~F}$ labelled FDG (2-Deoxy-2-fluoro-D-glucose) was synthesised from mannosyl triflate using a nucleophilic method. Radiochemical purity exceeded $95 \%$ and specific radioactivity was approximately $74 \mathrm{GBq} / \mu \mathrm{mol}$ at the end of synthesis. 
$\left[{ }^{18} \mathrm{~F}\right] \mathrm{EF} 5$ (FGF8b $n=11$, VEGF $n=12$ and mock $n=$ 29) and $\left[{ }^{18}\right.$ F]FDG (FGF8b $n=6$, VEGF $n=6$ and mock $n=5)$ were intravenously injected $(5.6 \pm 1.1$ and $6.6 \pm$ 1.4 MBq, respectively) into separate FGF8b (tumour weight $408 \pm 33 \mathrm{mg}$ ), VEGF (tumour weight $506 \pm$ $29 \mathrm{mg}$ ), and mock (tumour weight $408 \pm 20 \mathrm{mg}$ ) tumourbearing mice, and allowed to distribute 120 minutes before sacrifice. Blood, obtained by cardiac puncture, and tumour tissues were rapidly removed, counted for ${ }^{18} \mathrm{~F}$ radioactivity in a well counter $(3$ " $\times 3$ " $\mathrm{NaI}(\mathrm{TI})$ crystal, Bicron 3MW3/3P, Bicron Inc., Newbury, Ohio, USA) and weighed. The uptake of ${ }^{18} \mathrm{~F}$-radioactivity in tissues was calculated as percentage of injected dose per gram of tissue weight, taking into account the background from the counter measurements and the radioactivity decay. Tumour-to-blood uptake ratios ( $\mathrm{T} / \mathrm{B}$ ratios) were then calculated for both $\left[{ }^{18} \mathrm{~F}\right] \mathrm{EF} 5$ and $\left[{ }^{18} \mathrm{~F}\right] \mathrm{FDG}$. Plasma glucose levels were measured (Analox GM9, Analox Instruments Ltd., London, UK) in blood samples (FGF8b $n=$ 10 , VEGF $n=16$ and mock $n=11$ ).

The intratumoral distribution of $\left[{ }^{18} \mathrm{~F}\right] \mathrm{EF} 5$ and $\left[{ }^{18} \mathrm{~F}\right]$ FDG was studied in FGF8b, VEGF and mock tumourbearing mice using digital autoradiography. After sacrifice, tumours were removed, rapidly frozen in dry ice/ isopentane and cut with a cryomicrotome into $20 \mu \mathrm{m}$ thick sections. Tumour sections were then exposed to an imaging plate (Fuji BAS TR2025, Fuji Photo Film Co., Japan) for 3.5-4.5 hours. The spatial distribution of radioactivity from tumour sections was recorded with a phosphoimager (Fujifilm BAS-5000, Fuji Photo Film Co. Ltd., Tokyo, Japan). The dynamic linear range of this system is four decades, and the resolution (i.e. pixel size) of the images is $25 \times 25 \mu \mathrm{m}$.

The amount of 2-[ $\left.{ }^{18} \mathrm{~F}\right]$ fluoro-2-deoxyglucose-6phosphate $\left(\left[{ }^{18} \mathrm{~F}\right]\right.$ FDG-6-P), the main metabolite of $\left[{ }^{18} \mathrm{~F}\right]$ FDG, was determined in tumour homogenates (FGF8b $n=6$, VEGF $n=4$ and mock $n=3$ ) from animals injected with $\left[{ }^{18} \mathrm{~F}\right]$ FDG by using radioHPLC equipment (Merck Hitachi, Peterlee, UK).

\section{Oxygen partial pressure $\left(\mathrm{pO}_{2}\right)$ measurement}

In order to measure $\mathrm{pO}_{2}$ values in tumours, we used sterile, flexible polarographic electrodes (diameter 0.47 $\mathrm{mm}$ ) of the Clark type (Licox ${ }^{\odot}$ GMS, Kiel-Mielkendorf, Germany), supplied with a probe-specific microchip allowing automatic calibration. The probe was inserted into the tumour tissue by advancing it in a retrograde manner along the lumen of an insertion needle catheter, which was then removed. Tissue temperature was measured with a needle probe and temperature-adjusted $\mathrm{pO}_{2}(\mathrm{mmHg})$ was graphically displayed and stored digitally. The whole length of the oxygen-sensitive part of the probe was at least $2 \mathrm{~mm}$ inside the tumour throughout the measurements to prevent contamination from room-air $\mathrm{O}_{2}$. The duration of the $\mathrm{pO}_{2}$ measurement was sufficient to establish a stable $\mathrm{pO}_{2}$ level, which was then registered and stored. Three tumours from each group were measured over a time period of $20 \mathrm{~min}$ after a stabilisation period of approximately $5 \mathrm{~min}$. The gluteus muscle of the experimental animal served as a control site after measurements to verify the proper function of the Licox $^{\circledast}$ probe.

\section{Statistics}

All values are presented as mean \pm SD unless otherwise stated. Non-parametric one-way ANOVA (KruskalWallis test) with Dunn's post hoc test was used for statistical evaluation of CD31, Ki67, GLUT1, HIF1, necrosis, $\left[{ }^{18} \mathrm{~F}\right] \mathrm{FDG}$ uptake, amount of cells and $\mathrm{pO}_{2}$ values. One-way ANOVA with Tukey's post hoc test was used for statistical evaluation of plasma glucose levels and $\left[{ }^{18} \mathrm{~F}\right]$ EF5 uptake. The above statistical tests were performed using GraphPad Prism version 5.01 for Windows (GraphPad Software, San Diego, CA, USA), based on the distribution of the data (normal or nonparametric) and sample size. A $p$-value less than 0.05 was considered statistically significant.

\section{Results}

\section{Effects of FGF8b and VEGF on tumour growth and morphology}

In order to study the roles of FGF8b and VEGF in PC-3 tumours, we used xenografts of PC-3 cells ectopically expressing FGF8b and VEGF. Parental PC-3 cells do not express detectable levels of FGF8b [38] but they express VEGF at a low level (Figure 1). PC-3 cells transfected with FGF8b have been reported previously [38]. To obtain VEGF overexpressing PC-3 tumours, the cells were stably transfected with the expression vector pcDNA3.1(+) containing human VEGF cDNA at an ECORI site. PC-3 cells transfected with empty vectors were used as controls (mock). Expression of VEGF in the isolated clones was confirmed by Western blot analyses (Figure 1) and Northern blot analyses (data not shown). Several clones positive for VEGF were obtained, and one clone (PC-3/VEGF3, later called VEGF) was selected for in vivo studies.

Tumour growth associated with PC-3/FGF8b, PC-3/ VEGF and PC-3/mock cells was studied by inoculating them s.c. in the back of the necks of nude mice. The average growth (mean \pm SEM) of FGF8b, VEGF and mock tumours is shown in Figure 2A. Mock-transfected cells produced only small tumours $\left(749 \pm 19 \mathrm{~mm}^{3}\right)$, whereas FGF8b and VEGF tumours grew larger (3436 \pm $41 \mathrm{~mm}^{3}$ and $4036 \pm 51 \mathrm{~mm}^{3}$, respectively) during the 6 and 4-week study periods, respectively $(p<0.001)$.

Both FGF8b and VEGF tumours showed strong angiogenic morphology. They were reddish in colour and 


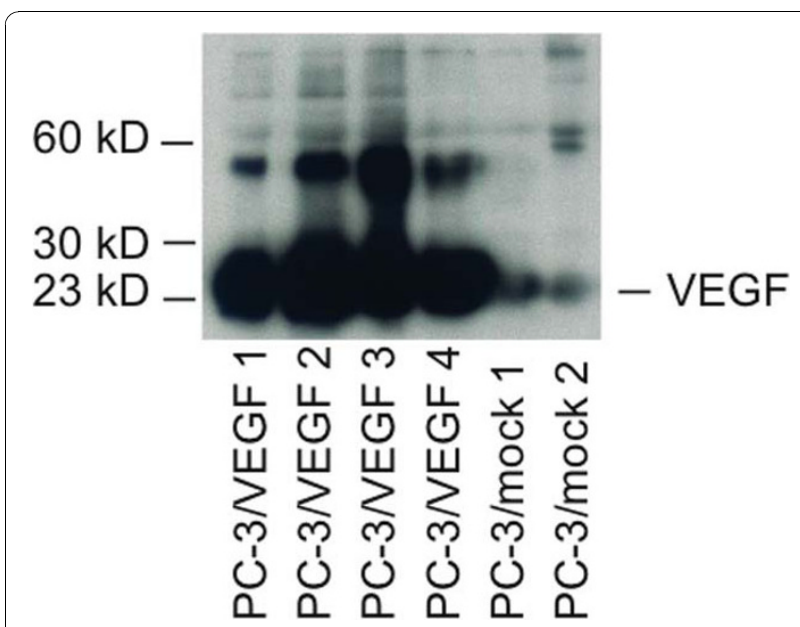

Figure 1 Expression of VEGF after transfection of PC-3 cells with VEGF or mock expression vectors. Western blot analysis of conditioned medium of PC-3/NEGF cell clones revealed several clones positive for $23 \mathrm{kD}$ VEGF protein. The larger bands at approximately $60 \mathrm{kD}$ may represent cleaved formes of larger splice variants in these cells. The expression level in mock cells was very low. One PC-3/NEGF clone (PC-3/NEGF3) and one PC-3/mock clone (PC-3/mock2) were selected for in vivo studies.

many of the FGF8b tumours were fragile and haemorrhagic. The morphology of mock tumours was solid, homogeneous and similar to parental PC-3 tumours. Morphological examination of the H\&E-stained sections showed a rich capillary network and large sinusoid-like vessels, especially in VEGF tumours (Figure 2B). Capillaries in FGF8b tumours looked more aberrant, containing large cisternal spaces filled with blood (Figure 2B). The number of capillaries was modest in mock tumours (Figure 2B). Vascularisation was verified using immunohistochemical staining for the endothelial marker CD31 and this procedure confirmed the differences in blood capillary density between these three different tumour types (Figure 2C). Significantly increased density of capillaries (mean \pm SEM, $p<0.001$ ) was seen in both FGF8b $\left(51 \pm 27 \mu \mathrm{m} / \mathrm{mm}^{2}\right)$ and VEGF $(97 \pm 4.51 \mu \mathrm{m} /$ $\mathrm{mm}^{2}$ ) tumours compared with that found in the mock tumours $\left(36 \pm 21 \mu \mathrm{m} / \mathrm{mm}^{2}\right.$, Figure $2 \mathrm{C}$-D).

The relative area of necrosis was measured in H\&Estained tumour sections. The data demonstrated that the relative area of necrosis was larger in the FGF8b tumours than in the VEGF $(p<0.05)$ or mock $(p<$ 0.01 ) tumours (Figure 2E).

\section{Cell cycle analysis and proliferation}

Cell cycle phases of FGF8b, VEGF and mock tumours were determined using flow cytometry. These analyses revealed a higher number of S-phase cells in both FGF8b (21\%) and VEGF (16\%) tumours compared with mock tumours (12\%) (data not shown). Immunohistochemical staining of tumour sections for Ki67 confirmed these findings (Figure 3), showing a significantly higher proliferation rate of FGF8b and VEGF tumours compared with that of mock tumours $(p<0.001)$. The percentage of Ki67-positive cells per $\mathrm{mm}^{2}$ was $26 \pm 11,33 \pm 10$ and $10 \pm 7$ in FGF8b, VEGF and mock tumours, respectively (Figure 3).

\section{Perfusion and oxygenation status of tumours}

The labelling intensity of the fluorescent perfusion marker Hoechst 33342 displayed distinct differences in perfusion patterns among the tumours. Labelling intensity was very weak in FGF8b tumours, indicating poor perfusion. As expected, the intensity was strongest in the VEGF tumours (Figure 4A), where signals were detected in both central and peripheral areas, suggesting that VEGF tumours are well perfused. Labelling intensity was modest in the mock tumours.

The nitroimidazole family compound EF5 forms covalent bonds with cellular macromolecules under hypoxic conditions, and therefore tends to accumulate at hypoxic sites $[45,46]$. The intratumoral distribution of $\left[{ }^{18} \mathrm{~F}\right] \mathrm{EF} 5$ determined by digital autoradiography in tumour sections showed a wide variation in the hotspot areas inside tumours (Figure 4B). The uptake pattern was very similar with that we have earlier detected and reported in regard to other hypoxia tracers [47]. It was not possible to ascertain clear divisions based on the intratumoral uptake pattern of $\left[{ }^{18} \mathrm{~F}\right] \mathrm{EF} 5$ according to tumour size, or the expression levels of the studied growth factors. In general, however, some distinguishable trends were detected. Variation in the intratumoral distribution of $\left[{ }^{18} \mathrm{~F}\right] \mathrm{EF} 5$ in smaller tumours ( $200 \mathrm{mg}$ ) was similar (data not shown) in all groups. Larger tumours $(\sim 500 \mathrm{mg})$ tend to show more uniformly distributed hotspots of $\left[{ }^{18} \mathrm{~F}\right] \mathrm{EF} 5$ uptake in VEGF-expressing tumours, whereas uptake of $\left[{ }^{18} \mathrm{~F}\right] \mathrm{EF} 5$ was primary located in peripheral parts of FGF8b- and mock-tumours (Figure 4B). The accumulation of $\left[{ }^{18} \mathrm{~F}\right]$ EF5, in whole tumours was measured after a distribution time of $120 \mathrm{~min}$. As shown in Figure 4C, a significantly lower T/B uptake ratio $(p<0.05)$ of $\left[{ }^{18} \mathrm{~F}\right] \mathrm{EF} 5$ was found in VEGF tumours $(1.45 \pm 0.37)$ compared with that measured in mock tumours $(1.81 \pm 0.45)$. The mean $\mathrm{T} / \mathrm{B}$ uptake ratio $(1.97 \pm 0.73)$ of $\left[{ }^{18} \mathrm{~F}\right] \mathrm{EF} 5$ in FGF8b tumours was not significantly different compared to VEGF or mock tumours (Figure 4C).

In order to confirm these findings, we measured the intratumoral partial pressure of oxygen $\left(\mathrm{pO}_{2}\right)$ using a Licox ${ }^{\oplus}$ Revoxode CC1.2 polarographic probe (Figure 4D). Significantly lower $(p<0.001)$ mean $\mathrm{pO}_{2}$ values were measured in both FGF8b and mock tumours $(2.3 \pm 0.6$ $\mathrm{mmHg}$ and $1.3 \pm 0.3 \mathrm{mmHg}$, respectively) compared with that in VEGF tumours $(17.4 \pm 2.2 \mathrm{mmHg})$. The $\mathrm{pO}_{2}$ value of the gluteus muscle, measured as a control, was $45 \mathrm{mmHg}$ (data not shown). 


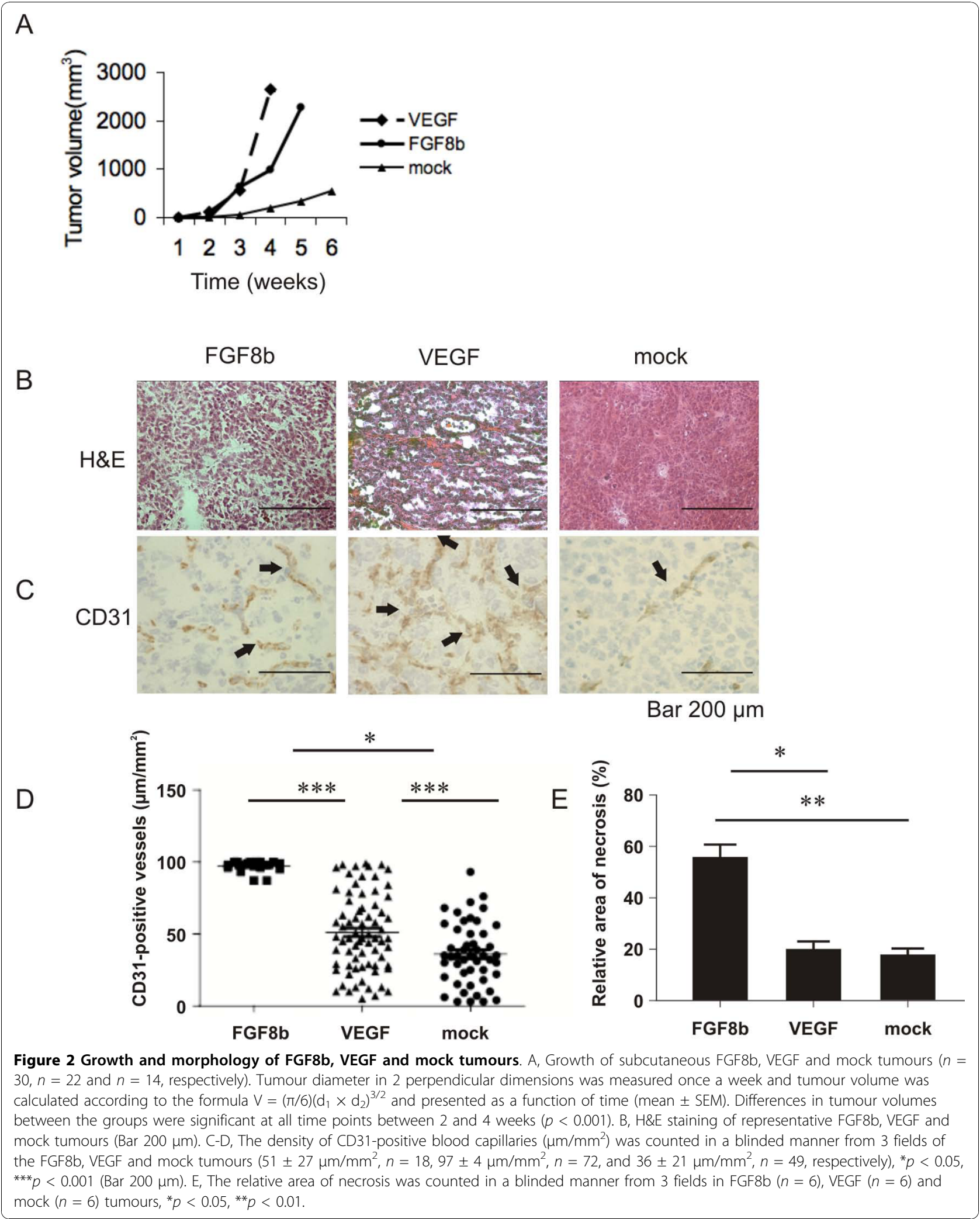




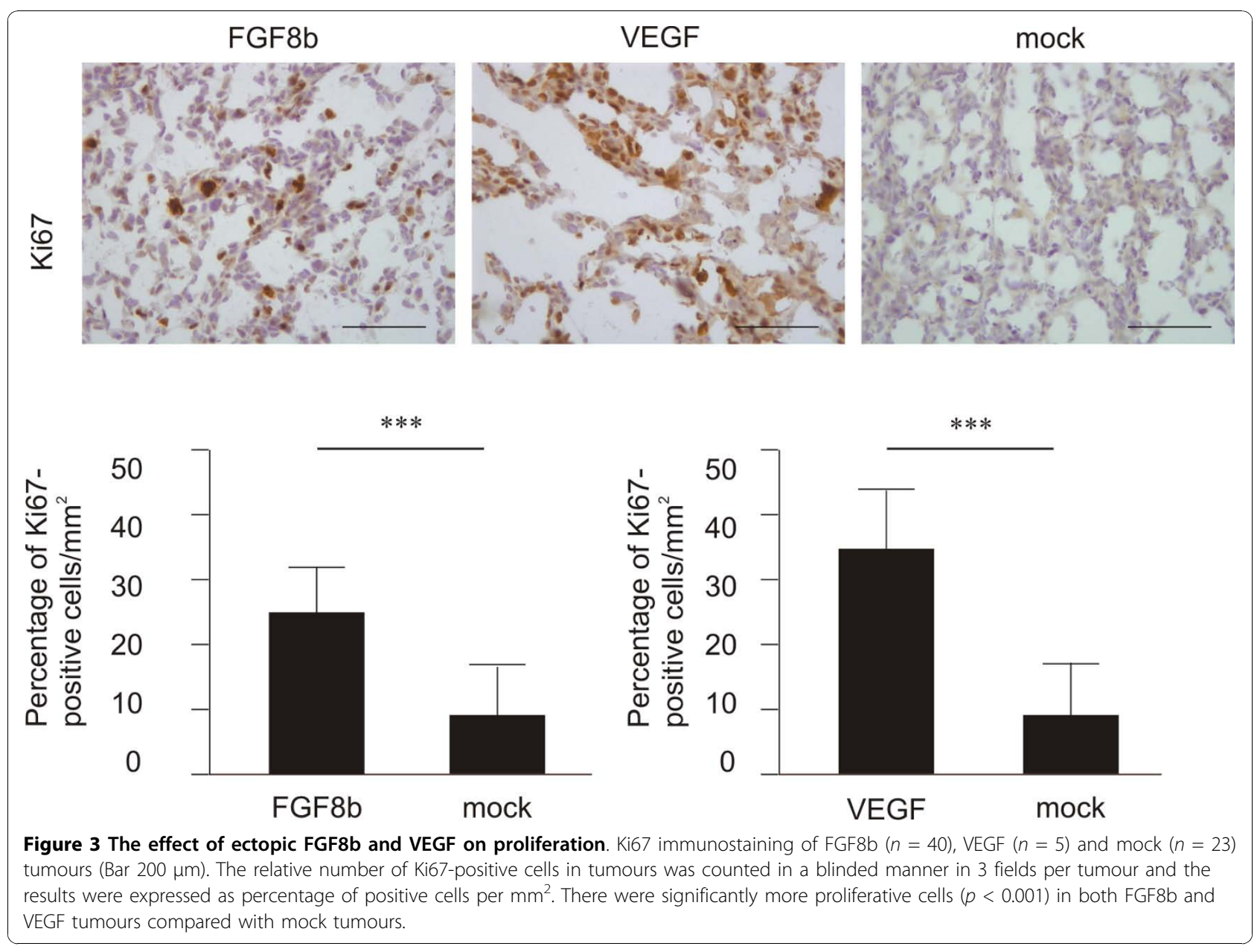

In addition to autoradiography, hypoxic clusters in FGF8b and mock tumors were also detected by immunostaining of hypoxia-inducible factor (HIF1 $\alpha$ ) [48,49]. As shown in Figure 5, the areas staining strongly for HIF1 $\alpha$ showed little immunopositivity for Ki67 whereas the areas with Ki67 positive cells did not markedly stain for HIF1.

\section{Metabolic activity of tumours}

In order to evaluate the metabolic activity of FGF8band VEGF-expressing tumours, we measured the uptake of $\left[{ }^{18} \mathrm{~F}\right] \mathrm{FDG}$-derived radioactivity. The intratumoral distribution of $\left[{ }^{18} \mathrm{~F}\right]$ FDG determined by digital autoradiography showed uniformly distributed uptake in tumours (Figure 6A). We found a significantly lower $(p<0.05)$ $\mathrm{T} / \mathrm{B}$ uptake ratio of $\left[{ }^{18} \mathrm{~F}\right] \mathrm{FDG}$ in FGF8b tumours $(7.4 \pm$ 0.7 ) compared with that seen in VEGF and mock tumours $(14.3 \pm 8.9$ and $17.8 \pm 9.3$, respectively), as shown in Figure 6B. The intracellular $\left[{ }^{18} \mathrm{~F}\right]$ FDG-6-P (the main metabolite of $\left[{ }^{18} \mathrm{~F}\right] \mathrm{FDG}$, which is trapped inside the cell) was detected by radioHPLC. The amount did not differ between the tumour groups (data not shown).
The mean plasma glucose level varied from 7.9 to 10.6 $\mathrm{mmol} / \mathrm{L}$ and was not significantly different in the three groups of tumour-bearing mice.

Since morphological studies indicated a lower number of cells in FGF8b tumours, which would affect the relative level of $\left[{ }^{18} \mathrm{~F}\right] \mathrm{FDG}$ uptake, we evaluated cellular density in the different tumour models by flow cytometry. Enumeration analysis showed that indeed FGF8b tumours contained fewer cells $/ \mathrm{cm}^{3}$ than VEGF and mock tumours (Figure 6B). A similar result was obtained by counting nuclei per field in $\mathrm{H} \& \mathrm{E}$-stained sections (data not shown). When the $\left[{ }^{18} \mathrm{~F}\right]$ FDG uptake (percentage of injected dose per gram tissue) was normalised to cell number, the differences between FGF8b and mock tumours disappeared, and according to the normalised data, the uptake was smallest in VEGF tumours (Figure 6B). Immunohistochemical staining of GLUT1 (Figure 6C) correlated with the uptake of $\left[{ }^{18} \mathrm{~F}\right]$ FDG, showing a trend towards a lower expression pattern of GLUT1 in VEGF tumours compared to mock tumours $(p<0.05)$. 


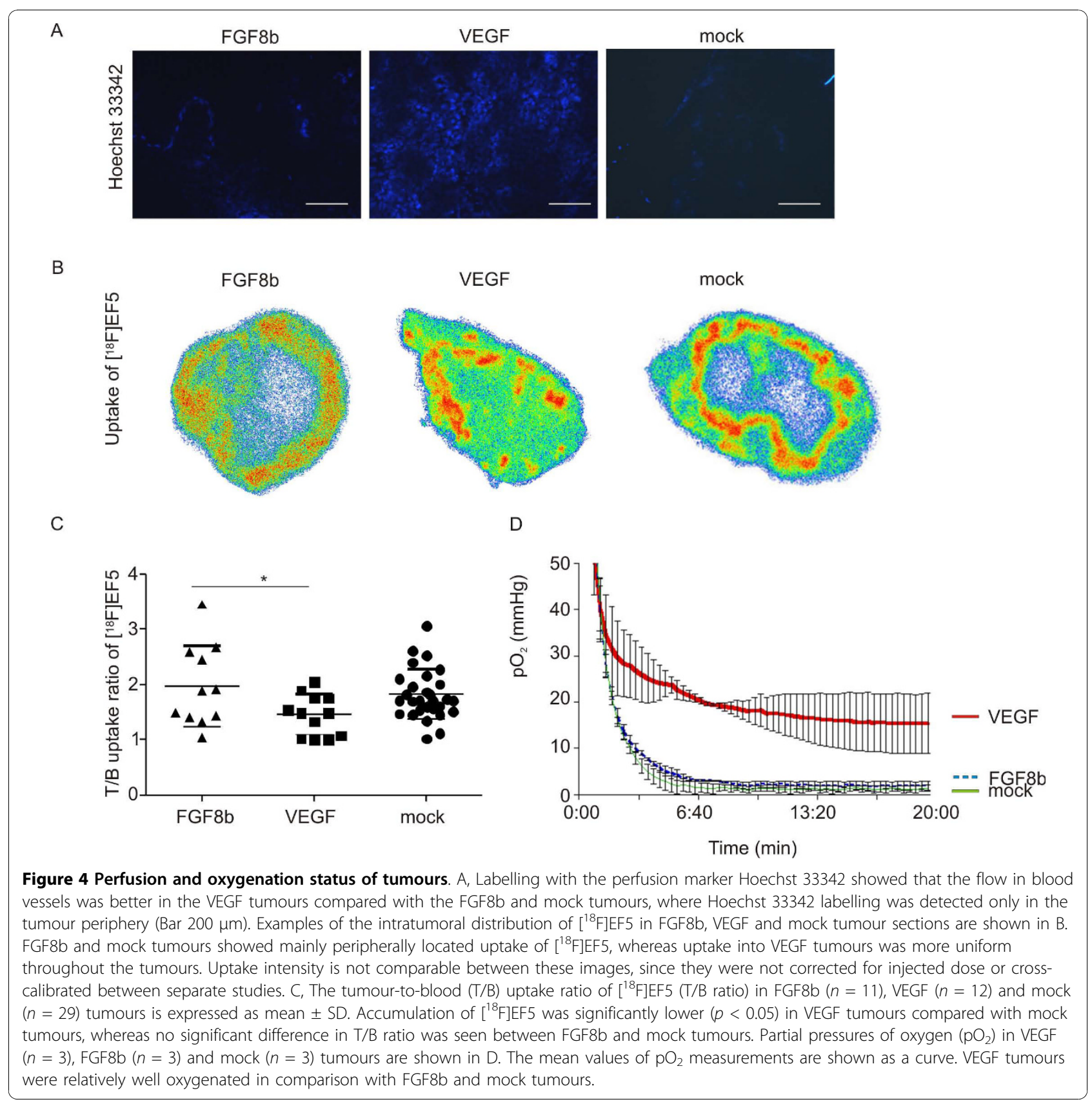

\section{Discussion}

Tumour vasculature provides necessary oxygen and nutrients for tumour growth, but it also plays a major role in metastatic spread. In prostate cancer, VEGFmediated angiogenesis has proved to be important for tumour growth and metastasis $[10,50]$. VEGF receptors are overexpressed in prostate cancer and plasma levels of VEGF are raised in metastatic disease compared with localised disease or healthy controls. Alterations in the vascular supply influence the tumour microenvironmental conditions, leading to changes in blood flow, $\mathrm{pH}$, glucose metabolism and oxygenation, which all may have significant effects on the responses of tumours to therapy [5]. Prostate tumours are typically very hypoxic. Hypoxia is known to induce a more aggressive phenotype, which increases metastatic potential, promotes tumour progression and limits the effectiveness of radiation therapy [2,51]. Tumour cells generally show increased glycolysis, even under aerobic conditions, and a rough correlation between the degree of malignancy and glycolytic rate has long been recognised [52]. 


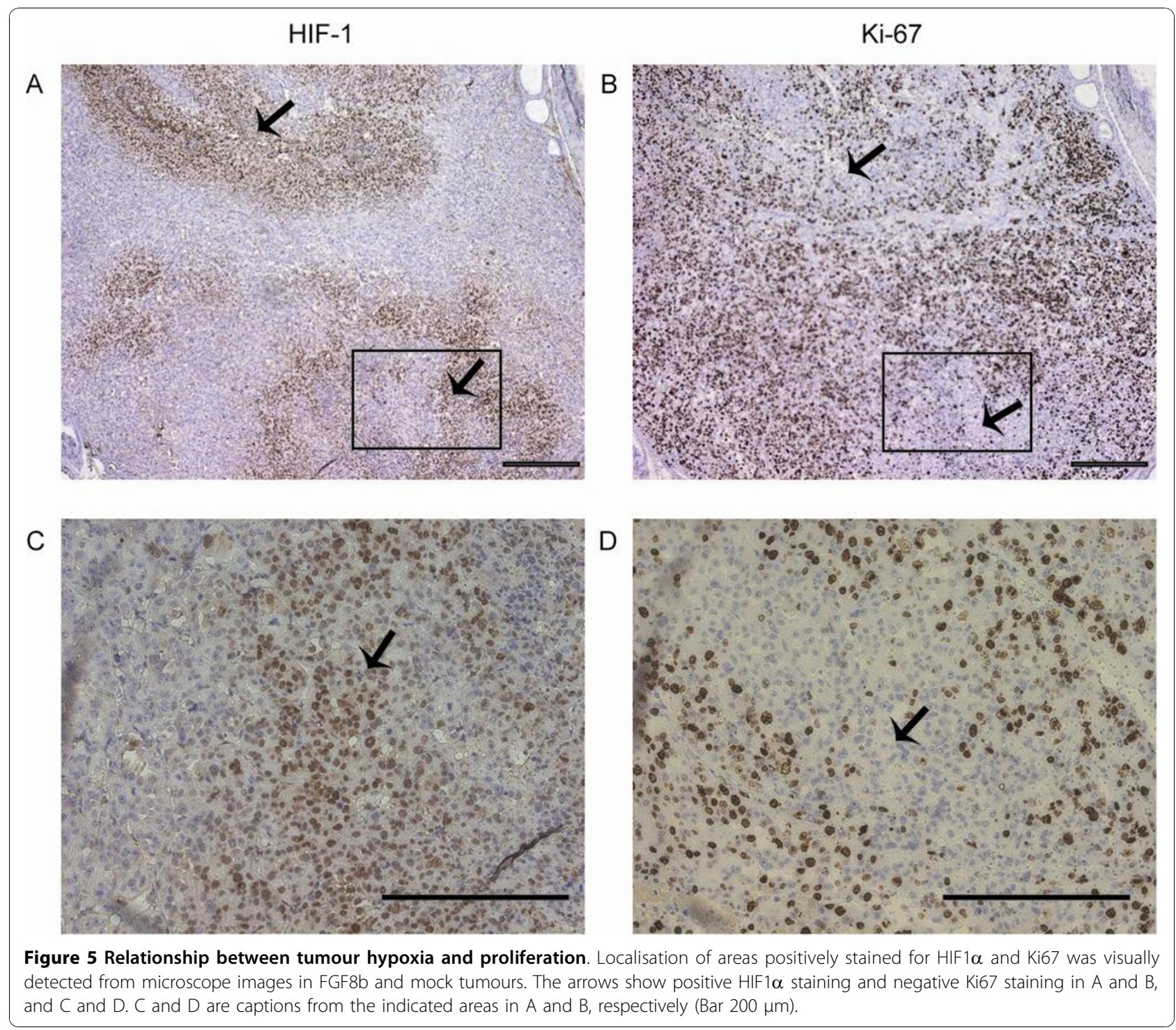

The purpose of this study was to evaluate the role of angiogenesis and tumour oxygenation in stimulation of growth of PC-3 prostate xenografts representing commonly hypoxic prostate cancer. Morphologic evaluation of PC-3 tumours overexpressing FGF8b, as well as those over-expressing VEGF, showed angiogenic morphology overall, compared with mock tumours. According to the results of our previous studies, FGF8b may be a key regulator of prostate cancer angiogenesis, supporting tumour growth [20]. We have previously shown that FGF8b increases angiogenic capacity in breast cancer cells and increases vessel sprouting in a chorion allantoic membrane assay $[34,35]$. In the present study, immunostaining with the endothelial marker CD31 confirmed that both FGF8band VEGF-expressing tumours had rich networks of capillaries, while in mock tumours the capillary network was sparse and individual capillaries were smaller. However, the capillary networks in angiogenic FGF8b- and VEGFexpressing tumours were not similar. Both tumour models showed large numbers of capillaries, but the capillary network was more distorted and non-continuous in FGF8b tumours. Areas of cisternal spaces filled with blood were also detected in FGF8b tumours. The accelerated growth rate of both FGF8b and VEGF tumours indicated an increased vessel capacity to support and contribute to tumour growth. FGF8 has also been shown to stimulate the rate of proliferation of PC-3 cells in vitro [20,36], while VEGF is a mitogenic factor affecting endothelial cells only. In the present study, the number of Ki67-positive cancer cells was significantly increased in both FGF8b and VEGF tumours (Figure 3). However, morphological examination of the tumours revealed significantly widened areas of necrosis in FGF8b tumours compared with the others. It has been previously shown that FGFs may not be able to 


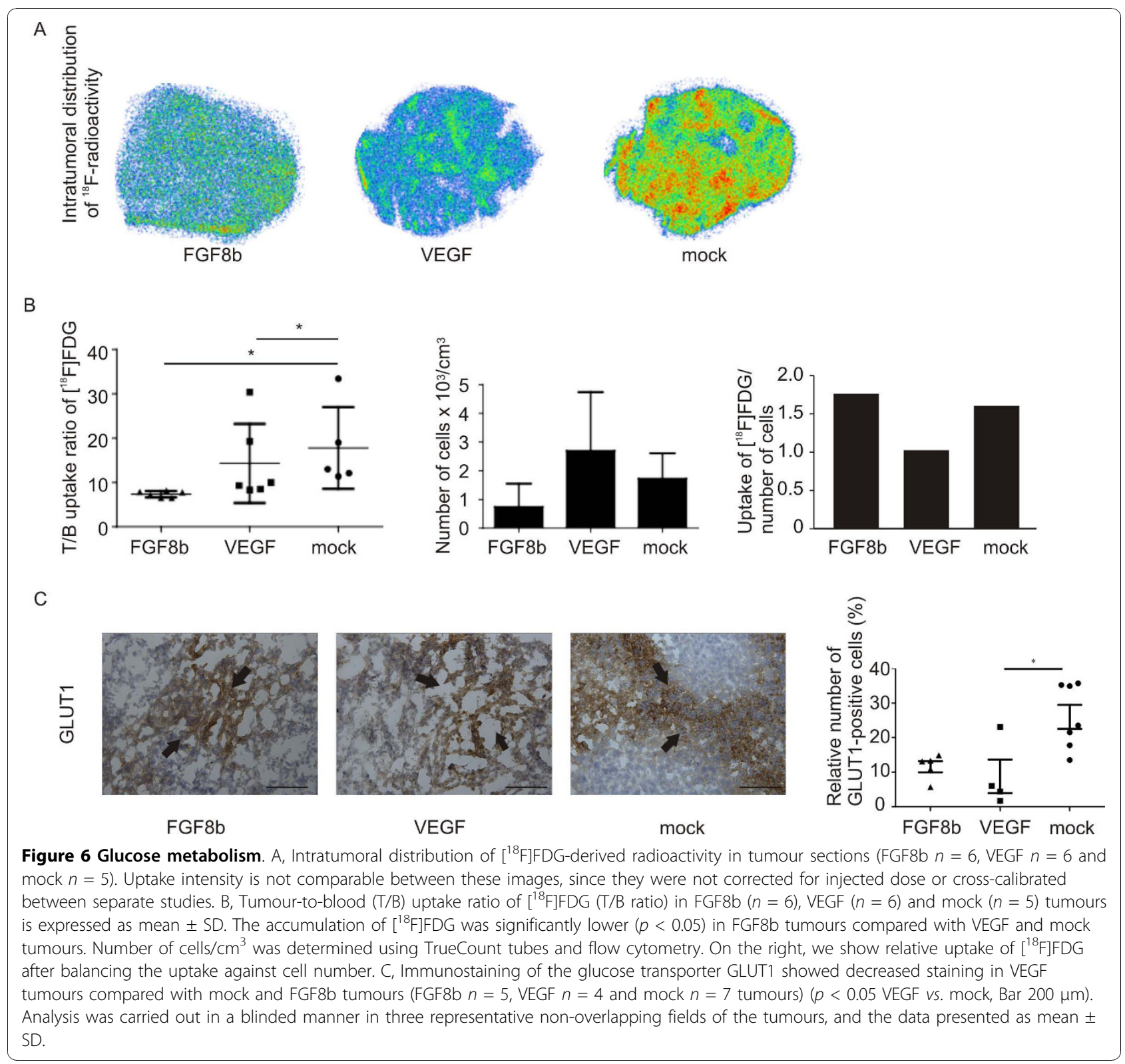

induce mature and fully functional capillaries without synergistic actions of other growth factors [53]. These findings made us question whether the capillaries in FGF8b tumours are able to function properly.

The performance of blood capillaries was studied by means of the perfusion marker Hoechst 33342, which revealed relatively low perfusion in mock tumours. Functional capillaries were seen only in the periphery of the tumours and they were sparse in central parts (Figure 4A). Despite the rich capillary network in FGF8b tumours, very low perfusion was detected, indicating that the rapid growth in comparison with mock tumours was caused by factors other than increased blood flow. It seems that the number of functional capillaries in FGF8b tumours is modest. The vessel-like structures could be a consequence of angiogenic mimicry, and these structures are not able to maintain proper oxygenation and support intratumoral cells. On the other hand, the VEGF tumours seemed to have an adequate number of functional capillaries. VEGF tumours were properly perfused, not only peripherally but also in central areas. Accordingly, the area of necrotic tissue in VEGF tumours was negligible.

Because of abnormal vasculature, hypoxia is very common in solid tumours. Since morphological evaluation and perfusion studies of the FGF8b tumours indicated that these vessels were not functioning normally, we decided to evaluate the proportion of hypoxic cells in the tumours. We found a significantly reduced T/B uptake 
ratio of the hypoxia tracer $\left[{ }^{18} \mathrm{~F}\right] \mathrm{EF} 5$ in VEGF tumourbearing animals, indicating that these tumours are indeed more perfused and oxygenated than the others (Figure 4). The intratumoral distribution of $\left[{ }^{18} \mathrm{~F}\right] \mathrm{EF} 5$ was studied autoradiographically. Uptake of $\left[{ }^{18} \mathrm{~F}\right] \mathrm{EF} 5$ was generally in accordance with the results of the perfusion study, showing a relatively high level of $\left[{ }^{18} \mathrm{~F}\right] \mathrm{EF} 5$ uptake in large peripheral regions of FGF8 $\mathrm{b}$ and mock tumours, whereas VEGF tumours showed a more uniform uptake, seen as smaller clusters throughout the tumour.

The partial pressure of oxygen $\left(\mathrm{pO}_{2}\right)$ seen in healthy tissues varies from $95 \mathrm{mmHg}$ in arterial blood to a mean value of about $40 \mathrm{mmHg}$ in tissues. Usually hypoxia is defined as an $\mathrm{O}_{2}$ concentration below 10 $\mathrm{mmHg}$ and $\mathrm{pO}_{2}$ values less than $5 \mathrm{mmHg}$ are generally considered as severe hypoxia [2]. According to our oxygen measurements, both the FGF8b and mock tumours were hypoxic, showing $\mathrm{pO}_{2}$ values of $2.3 \pm 0.6 \mathrm{mmHg}$ and $1.3 \pm 0.3 \mathrm{mmHg}$, respectively, whereas VEGF tumours were well oxygenated $(17.4 \pm 2.2 \mathrm{mmHg})$. Even if there were intratumoral necrotic areas, the difference seemed to be significant. Importantly, tumour hypoxia is generally considered as a poor prognostic factor [54]. In order to evaluate the hypoxia status of FGF8b and mock tumours further, we immunostained tumours against HIF1 $\alpha$, which mediates acute molecular responses to hypoxia [49]. The HIF1 $\alpha$-positive cells in FGF8b and mock tumours were seen as hypoxic clusters. When these clusters were visually evaluated from microscope images and compared to the expression of Ki67, we found a negatively related expression pattern.

In order to evaluate the metabolic activity of the tumours, we used $\left[{ }^{18} \mathrm{~F}\right] \mathrm{FDG}$, a glucose analogue, that is trapped inside metabolically active cells in the form of $\left[{ }^{18}\right.$ F]FDG-6-P [55]. As expected, relatively high uptake of $\left[{ }^{18} \mathrm{~F}\right]$ FDG was seen in all three tumour models. Surprisingly, the lowest T/B ratio was seen in FGF8b tumours. This can be partly explained by the lower cell density and increased intracellular space seen in the FGF8b tumours compared with the mock and VEGF tumours (Figure 2B and $6 \mathrm{C})$. When $\left[{ }^{18} \mathrm{~F}\right] \mathrm{FDG}$ uptake was balanced against cell number, the level of uptake in FGF8b tumours was similar to that in the mock tumours. Expression of the glucose transporter GLUT1 was also increased in FGF8b and mock tumours, which indicates that hypoxic tumours compensate for their hypoxia by increased glucose consumption [6]. Hypoxic cells often show enhanced glycolysis to maintain production of energy in the form of ATP without requiring $\mathrm{O}_{2}$ [6]. The results of several studies have shown a relationship between $\left[{ }^{18} \mathrm{~F}\right]$ FDG accumulation and GLUT1 expression in cancer [56]. The relationship between hypoxia and glucose metabolism might, however, be more complicated than is generally believed [57]. In a study by Rajendran et al. the authors found a wide variation in the relationship between hypoxia and energy metabolism in patients with different forms of cancer [58]. Acute hypoxia can stimulate anaerobic glycolysis in normal tissues and also in some tumours, but it is not a prime cause of glycolysis, which is the preferred means of energy metabolism in many tumours under aerobic conditions as well [6]. Glucose metabolism is also influenced by factors other than hypoxia, such as the number of tumour-infiltrating immunoreactive cells. Cellular proliferation might be reduced in chronically hypoxic regions, whereas the proliferation rate can be elevated in non-hypoxic tumour areas. This kind of cellular stress often activates other metabolic pathways as well, such as fatty acid synthetase (FAS) pathways [59]. Enhanced glycerolipid/free fatty acid cycling, on the other hand, favours tumour cell growth in environment poor in nutrients [60]. In addition, the expression of mitogenic FGF8b itself increases tumour growth. In clinical practice, high metabolic activity and hypoxia are considered to be characteristics of aggressive tumours [58]. Increased expression of FGF8b is known to predict poor clinical outcome of the patient $[17,32]$ but it remains to be studied whether hypoxic tumour microenvironment is associated with or contributes to FGF8b-driven tumour progression.

The limitation of our experimental study is that subcutaneous tumours instead of orthotopic tumours were used, which means heterotopic tumour microenvironment for tumour cells. The PC-3 control tumours formed were, however, hypoxic as clinical prostate tumours are. Another limitation is that the expression of FGF8b in PC-3 cells was not endogenous but produced by transfection of the ectopic gene which did not allow studies on the possible effects of silencing the gene on tumour microenvironment. Unfortunately, no prostate cancer cell line expressing FGF8 is available. Silencing endogenous VEGF would also add to the results of the role of VEGF in tumour oxygenation and tumour growth in our model. Additionally, studies of correlations of VEGF, FGF8 and HIF1 with each other and characteristics of clinical tumour samples and outcome of prostate cancer patients would clarify the role and significance of FGF8 in regulation of prostate cancer progression.

Our study revealed that our prostate tumour models have different profiles as regards hypoxia, perfusion and metabolism. The relationship between hypoxia and blood flow seems to be complex, and our results thus support the theory of variable oxygenation status coupled to a highly vascular morphology but differential numbers of functional vessels. Our results also support earlier evidence that hypoxia and accelerated glycolysis are common but independent phenomena in a malignant tumour phenotype. Our results are in line with those of studies on human prostate cancer, where the 
expression of FGF-8, VEGF and clinicopathological findings correlate with each other [61]. FGF8b could thus, alone or combined with other markers, be used as a prognostic indicator in cases of prostate cancer. It remains to be studied whether FGF8 expression is able to contribute to development of resistance to radiation and cytotoxic therapies of prostate cancer.

\section{Conclusions}

Our results suggest that while VEGF-increased prostate tumour growth is associated with and most probably caused by increased density and performance of the vascular network. Elevated tumour growth in FGF8b expressing xenografts is based on stimulated proliferative activity and increased hypoxia tolerance, which may promote prostate tumour progression to a more aggressive phenotype associated with resistance to radiation and cytotoxic therapies.

\section{Abbreviations}

AIGF: androgen-induced growth factor; DMEM: Dulbecco's modified Eagle's medium; ECL: enhanced chemiluminescence; EDTA: ethylenediaminetetraacetic acid; EF5: (2-(2-nitro-1H-imidazol-1-yl)-N-(2,2,3,3,3-pentafluoropropyl)acetamide); FAS: fatty acid synthetase; FDG: fluoro-2-deoxyglucose; FDG-6-P: fluoro-2-deoxyglucose-6-phosphate; FGF: fibroblast growth factor; FGFR: fibroblast growth factor receptor; GLUT: glucose transport protein; H\&E: hematoxylin-eosine; HPLC: high performance liquid chromatography; iFBS: heat-inactivated fetal bovine serum; IHC: immunohistochemistry; PBS: phosphate-buffered saline; PIN: prostatic intraepithelial neoplasia; pO2: partial oxygen pressure; s.c.: subcutaneous; T/B: tumour to blood ratio; VEGF: vascular endothelial growth factor.
\end{abstract}

\section{Acknowledgements}

We thank Ms. Soili Jussila, Mrs. Pirkko Rauhamäki and Ms. Sanna Auer from the Department of Cell Biology and Anatomy, Veronica Fagerholm, Ph.D., from the Turku PET Centre and Mrs. Seija Lindqvist from the Turku University Central Animal laboratory for excellent technical assistance. Dr. Cameron Koch from the University of Pennsylvania is warmly thanked for collaboration and for providing the EF5 precursor. Finally, we thank Professor Kari Alitalo from the University of Helsinki for providing us with the VEGF gene construct and for his expertise concerning angiogenesis. This work was supported by grants from the Academy of Finland, the Finnish Cancer Societies, the Sigrid Jusélius Foundation, the South-Western Finnish Cancer Societies and the Foundation for the Finnish Cancer Institute.

\section{Author details}

${ }^{1}$ Institute of Biomedicine, Department of Cell Biology and Anatomy, University of Turku, Turku, Finland. ${ }^{2}$ Pharmatest Services Ltd., Turku, Finland. ${ }^{3}$ Turku PET Centre, MediCity Preclinical Research Laboratory, University of Turku and Åbo Akademi University, Turku, Finland. ${ }^{4}$ Cell Imaging Core, Turku Centre for Biotechnology, University of Turku and Åbo Akademi University, Turku, Finland. ${ }^{5}$ Department of Otorhinolaryngology - Head and Neck Surgery, Turku University Hospital, University of Turku, Turku, Finland. ${ }^{6}$ Turku PET Centre, Radiopharmaceutical Chemistry Laboratory, University of Turku and Åbo Akademi University, Turku, Finland. ${ }^{7}$ Turku PET Centre, Accelerator Laboratory, MediCity Preclinical Research Laboratory, University of Turku and Åbo Akademi University, Turku, Finland. ${ }^{8}$ Department of Oncology and Radiotherapy, Turku University Hospital, Turku, Finland. ${ }^{9}$ Department of Laboratory Medicine, MAS University Hospital, Lund University, Malmö, Sweden.

\section{Authors' contributions}

JT carried out the cell cultures, RNA isolation, Northern Blot analysis, Western Blot analysis, analysis of morphology and morphometry. Transfection of the
PC-3 cell was done by MV and JSe. Tumour experiments were done by JT and TG. Flow cytometric analysis was made by JSa. AS and IK helped with partial oxygen measurement. PM helped with processing the tumours. SF made the radiochemical synthesis of tracers. TG made the analysis of uptake of tracers and statistical analysis. $\mathrm{PH}, \mathrm{HM}$ and $\mathrm{OS}$ participated in the design of the study. JT wrote the first version of the manuscript and all authors helped to process it. All authors have read and approved the final manuscript. PH gave final approval for the manuscript to be submitted.

\section{Competing interests}

The authors declare that they have no competing interests.

Received: 1 April 2010 Accepted: 30 October 2010

Published: 30 October 2010

\section{References}

1. Stewart GD, Ross JA, McLaren DB, Parker CC, Habib FK, Riddick AC: The relevance of a hypoxic tumour microenvironment in prostate cancer. BJU Int 2010, 105(1):8-13.

2. Brown JM, Wilson WR: Exploiting tumour hypoxia in cancer treatment. Nat Rev Cancer 2004, 4(6):437-47.

3. Jokilehto T, Rantanen K, Luukkaa M, Heikkinen P, Grenman R, Minn H, Kronqvist $\mathrm{P}$, Jaakkola PM: Overexpression and nuclear translocation of hypoxia-inducible factor prolyl hydroxylase PHD2 in head and neck squamous cell carcinoma is associated with tumor aggressiveness. Clin Cancer Res 2006, 12(4):1080-7.

4. Pennacchietti S, Michieli P, Galluzzo M, Mazzone M, Giordano S, Comoglio PM: Hypoxia promotes invasive growth by transcriptional activation of the met protooncogene. Cancer Cell 2003, 3(4):347-61.

5. Vaupel P, Harrison L: Tumor hypoxia: Causative factors, compensatory mechanisms, and cellular response. Oncologist 2004, 9(Suppl 5):4-9.

6. Gatenby RA, Gillies RJ: Why do cancers have high aerobic glycolysis? Nat Rev Cancer 2004, 4(11):891-9.

7. Mellanen P, Minn H, Grenman R, Härkönen P: Expression of glucose transporters in head-and-neck tumors. Int J Cancer 1994, 56(5):622-9.

8. Stewart GD, Gray K, Pennington CJ, Edwards DR, Riddick AC, Ross JA, Habib FK: Analysis of hypoxia-associated gene expression in prostate cancer: Lysyl oxidase and glucose transporter-1 expression correlate with gleason score. Oncol Rep 2008, 20(6):1561-7.

9. Harris AL: Hypoxia-a key regulatory factor in tumour growth. Nat Rev Cancer 2002, 2(1):38-47.

10. Folkman J: Tumor angiogenesis: Therapeutic implications. N Engl J Med 1971, 285(21):1182-6.

11. Hanahan D, Folkman J: Patterns and emerging mechanisms of the angiogenic switch during tumorigenesis. Cell 1996, 86(3):353-64.

12. Benjamin LE, Golijanin D, Itin A, Pode D, Keshet E: Selective ablation of immature blood vessels in established human tumors follows vascular endothelial growth factor withdrawal. J Clin Invest 1999, 103(2):159-65.

13. Ferrara N, Carver-Moore K, Chen H, Dowd M, Lu L, O'Shea KS, PowellBraxton L, Hillan KJ, Moore MW: Heterozygous embryonic lethality induced by targeted inactivation of the VEGF gene. Nature 1996, 380(6573):439-42.

14. Senger DR, Brown LF, Claffey KP, Dvorak HF: Vascular permeability factor, tumor angiogenesis and stroma generation. Invasion Metastasis 1994, 14(1-6):385-94.

15. Green MM, Hiley CT, Shanks JH, Bottomley IC, West CM, Cowan RA, Stratford IJ: Expression of vascular endothelial growth factor (VEGF) in locally invasive prostate cancer is prognostic for radiotherapy outcome. Int J Radiat Oncol Biol Phys 2007, 67(1):84-90.

16. Shariat SF, Anwuri VA, Lamb DJ, Shah NV, Wheeler TM, Slawin KM: Association of preoperative plasma levels of vascular endothelial growth factor and soluble vascular cell adhesion molecule-1 with lymph node status and biochemical progression after radical prostatectomy. J Clin Oncol 2004, 22(9):1655-63.

17. Gnanapragasam VJ, Robinson MC, Marsh C, Robson CN, Hamdy FC, Leung HY: FGF8 isoform $\mathrm{b}$ expression in human prostate cancer. $\mathrm{Br} J$ Cancer 2003, 88(9):1432-8.

18. Powers CJ, McLeskey SW, Wellstein A: Fibroblast growth factors, their receptors and signaling. Endocr Relat Cancer 2000, 7(3):165-97. 
19. Suzuki M, Satoh A, Ide H, Tamura K: Nerve-dependent and -independent events in blastema formation during xenopus froglet limb regeneration. Dev Biol 2005, 286(1):361-75.

20. Valta MP, Tuomela J, Vuorikoski H, Loponen N, Väänänen RM, Pettersson $\mathrm{K}$, Väänänen HK, Härkönen PL: FGF-8b induces growth and rich vascularization in an orthotopic PC-3 model of prostate cancer. J Cell Biochem 2009, 107(4):769-84.

21. Valta MP, Hentunen $T, Q u$ Q, Valve EM, Harjula A, Seppänen JA, Väänänen HK, Härkönen PL: Regulation of osteoblast differentiation: A novel function for fibroblast growth factor 8. Endocrinology 2006, 147(5):2171-82.

22. Kwabi-Addo B, Ozen M, Ittmann M: The role of fibroblast growth factors and their receptors in prostate cancer. Endocr Relat Cancer 2004, 11(4):709-24.

23. Mattila MM, Härkonen PL: Role of fibroblast growth factor 8 in growth and progression of hormonal cancer. Cytokine Growth Factor Rev 2007, 18(3-4):257-66.

24. Doll JA, Reiher FK, Crawford SE, Pins MR, Campbell SC, Bouck NP: Thrombospondin-1, vascular endothelial growth factor and fibroblast growth factor- 2 are key functional regulators of angiogenesis in the prostate. Prostate 2001, 49(4):293-305.

25. Huss WJ, Barrios RJ, Foster BA, Greenberg NM: Differential expression of specific FGF ligand and receptor isoforms during angiogenesis associated with prostate cancer progression. Prostate 2003, 54(1):8-16.

26. Valve EM, Nevalainen MT, Nurmi MJ, Laato MK, Martikainen PM, Härkonen PL: Increased expression of FGF-8 isoforms and FGF receptors in human premalignant prostatic intraepithelial neoplasia lesions and prostate cancer. Lab Invest 2001, 81(6):815-26.

27. Heer R, Douglas D, Mathers ME, Robson CN, Leung HY: Fibroblast growth factor 17 is over-expressed in human prostate cancer. J Pathol 2004, 204(5):578-86

28. Tanaka A, Miyamoto K, Minamino N, Takeda M, Sato B, Matsuo H, Matsumoto $\mathrm{K}$ : Cloning and characterization of an androgen-induced growth factor essential for the androgen-dependent growth of mouse mammary carcinoma cells. Proc Natl Acad Sci USA 1992, 89(19):8928-32.

29. Ghosh AK, Shankar DB, Shackleford GM, Wu K, T'Ang A, Miller GJ, Zheng J, Roy-Burman P: Molecular cloning and characterization of human FGF8 alternative messenger RNA forms. Cell Growth Differ 1996, 7(10):1425-34.

30. Song Z, Wu X, Powell WC, Cardiff RD, Cohen MB, Tin RT, Matusik RJ, Miller GJ, Roy-Burman P: Fibroblast growth factor 8 isoform B overexpression in prostate epithelium: $A$ new mouse model for prostatic intraepithelial neoplasia. Cancer Res 2002, 62(17):5096-105

31. Tanaka A, Furuya A, Yamasaki M, Hanai N, Kuriki K, Kamiakito T, Kobayashi Y, Yoshida H, Koike M, Fukayama M: High frequency of fibroblast growth factor (FGF) 8 expression in clinical prostate cancers and breast tissues, immunohistochemically demonstrated by a newly established neutralizing monoclonal antibody against FGF 8 . Cancer Res 1998 58(10):2053-6.

32. Dorkin TJ, Robinson MC, Marsh C, Bjartell A, Neal DE, Leung HY: FGF8 overexpression in prostate cancer is associated with decreased patient survival and persists in androgen independent disease. Oncogene 1999, 18(17):2755-61.

33. Ornitz DM, Xu J, Colvin JS, McEwen DG, MacArthur CA, Coulier F, Gao G, Goldfarb M: Receptor specificity of the fibroblast growth factor family. $J$ Biol Chem 1996, 271(25):15292-7.

34. Ruohola JK, Viitanen TP, Valve EM, Seppänen JA, Loponen NT, Keskitalo JJ, Lakkakorpi PT, Härkönen PL: Enhanced invasion and tumor growth of fibroblast growth factor 8b-overexpressing MCF-7 human breast cancer cells. Cancer Res 2001, 61(10):4229-37.

35. Mattila MM, Ruohola JK, Valve EM, Tasanen MJ, Seppänen JA, Härkönen PL FGF-8b increases angiogenic capacity and tumor growth of androgenregulated S115 breast cancer cells. Oncogene 2001, 20(22):2791-804.

36. Song Z, Powell WC, Kasahara N, van Bokhoven A, Miller GJ, Roy-Burman P. The effect of fibroblast growth factor 8 , isoform $b$, on the biology of prostate carcinoma cells and their interaction with stromal cells. Cancer Res 2000, 60(23):6730-6.

37. Rudra-Ganguly N, Zheng J, Hoang AT, Roy-Burman P: Downregulation of human FGF8 activity by antisense constructs in murine fibroblastic and human prostatic carcinoma cell systems. Oncogene 1998, 16(11):1487-92.
38. Valta MP, Tuomela J, Bjartell A, Valve E, Väänänen HK, Härkönen P: FGF-8 is involved in bone metastasis of prostate cancer. Int J Cancer 2008, 123(1):22-31.

39. Leung DW, Cachianes G, Kuang WJ, Goeddel DV, Ferrara N: Vascular endothelial growth factor is a secreted angiogenic mitogen. Science 1989, 246(4935):1306-9.

40. Chomczynski P, Sacchi N: Single-step method of RNA isolation by acid guanidinium thiocyanate-phenol-chloroform extraction. Anal Biochem 1987, 162(1):156-9.

41. Ruohola JK, Valve EM, Vainikka S, Alitalo K, Härkönen PL: Androgen and fibroblast growth factor (FGF) regulation of FGF receptors in $\mathrm{S} 115$ mouse mammary tumor cells. Endocrinology 1995, 136(5):2179-88.

42. Ruohola JK, Valve EM, Kärkkäinen MJ, Joukov V, Alitalo K, Härkönen PL: Vascular endothelial growth factors are differentially regulated by steroid hormones and antiestrogens in breast cancer cells. Mol Cell Endocrinol 1999, 149(1-2):29-40.

43. Wärri AM, Huovinen RL, Laine AM, Martikainen PM, Härkönen PL: Apoptosis in toremifene-induced growth inhibition of human breast cancer cells in vivo and in vitro. J Natl Cancer Inst 1993, 85(17):1412-8.

44. Tuomela JM, Valta MP, Väänänen $\mathrm{K}$, Härkönen PL: Alendronate decreases orthotopic PC-3 prostate tumor growth and metastasis to prostatedraining lymph nodes in nude mice. BMC Cancer 2008, 8:81.

45. Bergman J, Solin O: Fluorine-18-labeled fluorine gas for synthesis of tracer molecules. Nucl Med Biol 1997, 24(7):677-83.

46. Evans SM, Judy KD, Dunphy I, Jenkins WT, Nelson PT, Collins R, Wileyto EP, Jenkins K, Hahn SM, Stewens CW, Judkins AR, Philips P, Geoerger B, Koch $\mathrm{CJ}$ : Comparative measurements of hypoxia in human brain tumors using needle electrodes and EF5 binding. Cancer Res 2004, 64(5):1886-92.

47. Grönroos T, Bentzen L, Marjamäki P, Murata R, Horsman MR, Keiding S, Eskola O, Haaparanta M, Minn H, Solin O: Comparison of the biodistribution of two hypoxia markers [18F]FETNIM and [18F]FMISO in an experimental mammary carcinoma. Eur J Nucl Med Mol Imaging 2004, 31(4):513-20.

48. Jaakkola P, Mole DR, Tian YM, Wilson MI, Gielbert J, Gaskell SJ, Kriegsheim A Hebestreit HF, Mukherji M, Schofield CJ, Maxwell PH, Pugh CW, Ratcliffe PJ: Targeting of HIF-alpha to the von hippel-lindau ubiquitylation complex by O2-regulated prolyl hydroxylation. Science 2001, 292(5516):468-72.

49. Wang GL, Semenza GL: Purification and characterization of hypoxiainducible factor 1. J Biol Chem 1995, 270(3):1230-7.

50. Siddiqui K, Klotz LH: Emerging drugs for prostate cancer. Expert Opin Emerg Drugs 2009, 14(3):455-70.

51. Minn H, Grönroos TJ, Komar G, Eskola O, Lehtiö K, Tuomela J, Seppänen M, Solin O: Imaging of tumor hypoxia to predict treatment sensitivity. Curr Pharm Des 2008, 14(28):2932-42.

52. Semenza GL, Artemov D, Bedi A, Bhujwalla Z, Chiles K, Feldser D, Laughner E, Ravi R, Simons J, Taghavi P, Zheng H: 'The metabolism of tumours': 70 years later. Novartis Found Symp 2001, 240:251, 60; discussion 260-4.

53. Cao R, Brakenhielm E, Pawliuk R, Wariaro D, Post MJ, Wahlberg E, Leboulch P, Cao Y: Angiogenic synergism, vascular stability and improvement of hind-limb ischemia by a combination of PDGF-BB and FGF-2. Nat Med 2003, 9(5):604-13.

54. Sutherland RM, Ausserer WA, Murphy BJ, Laderoute KR: Tumor hypoxia and heterogeneity: Challenges and opportunities for the future. Semin Radiat Oncol 1996, 6(1):59-70.

55. Castell F, Cook GJ: Quantitative techniques in 18FDG PET scanning in oncology. Br J Cancer 2008, 98(10):1597-601.

56. Airley RE, Mobasheri A: Hypoxic regulation of glucose transport, anaerobic metabolism and angiogenesis in cancer: Novel pathways and targets for anticancer therapeutics. Chemotherapy 2007, 53(4):233-56

57. Komar G, Seppänen M, Eskola O, Lindholm P, Grönroos TJ, Forsback S, Sipilä H, Evans SM, Solin O, Minn H: 18F-EF5: A new PET tracer for imaging hypoxia in head and neck cancer. J Nucl Med 2008, 49(12):1944-51.

58. Rajendran JG, Mankoff DA, O'Sullivan F, Peterson LM, Schwartz DL Conrad EU, Spence AM, Muzi M, Farwell DG, Krohn KA: Hypoxia and glucose metabolism in malignant tumors: Evaluation by [18F] fluoromisonidazole and [18F]fluorodeoxyglucose positron emission tomography imaging. Clin Cancer Res 2004, 10(7):2245-52. 
59. Menendez JA, Lupu R: Oncogenic properties of the endogenous fatty acid metabolism: Molecular pathology of fatty acid synthase in cancer cells. Curr Opin Clin Nutr Metab Care 2006, 9(4):346-57.

60. Prentki M, Madiraju SR: Glycerolipid metabolism and signaling in health and disease. Endocr Rev 2008, 29(6):647-76.

61. West AF, O'Donnell M, Charlton RG, Neal DE, Leung HY: Correlation of vascular endothelial growth factor expression with fibroblast growth factor-8 expression and clinico-pathologic parameters in human prostate cancer. Br J Cancer 2001, 85(4):576-83.

\section{Pre-publication history}

The pre-publication history for this paper can be accessed here: http://www.biomedcentral.com/1471-2407/10/596/prepub

doi:10.1186/1471-2407-10-596

Cite this article as: Tuomela et al:: Fast growth associated with aberrant vasculature and hypoxia in fibroblast growth factor $8 \mathrm{~b}$ (FGF8b) overexpressing PC-3 prostate tumour xenografts. BMC Cancer 2010 10:596.

\section{Submit your next manuscript to BioMed Central} and take full advantage of:

- Convenient online submission

- Thorough peer review

- No space constraints or color figure charges

- Immediate publication on acceptance

- Inclusion in PubMed, CAS, Scopus and Google Scholar

- Research which is freely available for redistribution

Submit your manuscript at www.biomedcentral.com/submit 